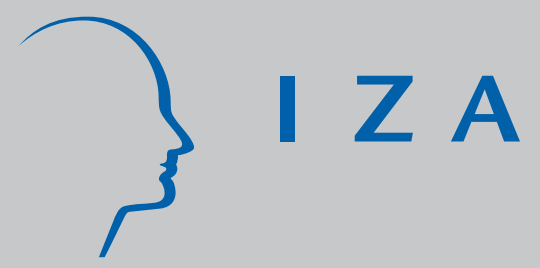

IZA DP No. 497

European Integration and Employment:

A New Role for Active Fiscal Policies?

Donatella Gatti

May 2002 


\title{
European Integration and Employment: A New Role for Active Fiscal Policies?
}

\author{
Donatella Gatti \\ University of Lille 2, MODEM and CEPREMAP
}

\author{
Discussion Paper No. 497 \\ May 2002
}

\author{
IZA \\ P.O. Box 7240 \\ D-53072 Bonn \\ Germany \\ Tel.: +49-228-3894-0 \\ Fax: +49-228-3894-210 \\ Email: iza@iza.org
}

This Discussion Paper is issued within the framework of IZA's research area Internationalization of Labor Markets. Any opinions expressed here are those of the author(s) and not those of the institute. Research disseminated by IZA may include views on policy, but the institute itself takes no institutional policy positions.

The Institute for the Study of Labor (IZA) in Bonn is a local and virtual international research center and a place of communication between science, politics and business. IZA is an independent, nonprofit limited liability company (Gesellschaft mit beschränkter Haftung) supported by the Deutsche Post AG. The center is associated with the University of Bonn and offers a stimulating research environment through its research networks, research support, and visitors and doctoral programs. IZA engages in (i) original and internationally competitive research in all fields of labor economics, (ii) development of policy concepts, and (iii) dissemination of research results and concepts to the interested public. The current research program deals with (1) mobility and flexibility of labor, (2) internationalization of labor markets, (3) welfare state and labor markets, (4) labor markets in transition countries, (5) the future of labor, (6) evaluation of labor market policies and projects and (7) general labor economics.

IZA Discussion Papers often represent preliminary work and are circulated to encourage discussion. Citation of such a paper should account for its provisional character. A revised version may be available on the IZA website (www.iza.org) or directly from the author. 


\section{ABSTRACT}

\section{European Integration and Employment: A New Role for Active Fiscal Policies?*}

This paper theoretically investigates the impact of European integration on employment by developing a new-keynesian model where fiscal policy effectively reduces firms' market power. Stronger product market competition is shown to reduce the marginal ability of governments to improve employment through public consumption. As competition crowds out fiscal spending, the positive impact of markets integration on employment is weakened. Moreover, in a context where national goods' demand becomes "global", the marginal benefit for each national fiscal authority of increasing public consumption is lower than the marginal benefit for the community. This result stresses one source of coordination failure within the EMU.

JEL Classification: E24, F02, F42, J41

Keywords: product market integration, fiscal policy, coordination, equilibrium unemployment

Donatell Gatti

MODEM

Université de Paris X - Nanterre

200 avenue de la République

92001 Nanterre Cedex

France

Tel.: +33140778408

Fax: +33144243857

Email: dgatti@u-paris10.fr

\footnotetext{
* The author is grateful to Torben Andersen, Thomas Beissinger and participants to the IZA Workshop European Integration and Labor Market Performance for comments and suggestions on the paper. Helpful remarks by participants to the RES 2002 conference (Warwick) and the SASE 2001 meeting (Amsterdam) are also gratefully acknowledged. The author is indebted to Bruno Amable, Robert Boyer, David Soskice and Christa van Wijnbergen for the many discussions on the topic. The usual caveats apply.
} 


\section{Introduction}

This paper is a theoretical contribution investigating the links between the macroeconomic policy regime and the structure of product and labor markets within EMU. Recent economic literature has shown a growing interest in issues related to EMU good working. Concerns have mainly been raised about existing asymmetries across countries as well as the extent to which effective wage coordination might take place within EMU (Soskice and Iversen, 1998). With respect to the overall macroeconomic policy regime, much has been said concerning the possible effects of economic integration on national governments' actions: this debate has focused on the impact of integration on the size and scope of governments' interventions mostly in relation to the future role of welfare states within EMU (Anderson, 1999). In spite of the large amount of research done on EMU-related issues, relatively little has been said on the interactions between the nature of EMU policy mix (particularly countercyclical fiscal policies) and the changing structure of labor and product markets. However, one crucial outcome of EMU is precisely an increase in competition on national product markets, which is itself bound to have an impact on labor markets structure (Amable and Gatti, 2002). This paper suggests that this process will also affect the nature of the "optimal" policy mix, and more precisely the role and operation of countercyclical national fiscal policies.

The role of fiscal policies has partially been neglected in recent debates because the Stability and Growth Pact (SGP) is thought to impose too stringent conditions on member countries, which prevent them to run any effective fiscal policy. Indeed, the main rationale behind the SGP is to overcome the individual temptation for excessive government expenditure (Canzoneri and Diba, 1999; Buti et al., 1998). For instance, Beetsma and Uhlig (1999:547) submit that 'the essence of the Stability and Growth Pact is to watch the fiscal deficit of each member country closely, and punish those, whose deficits are excessive'. Partially driven by fears that fiscal spending would be upward-biased in EMU, the SGP has been criticized by authors pointing out that a crucial priority for EMU economies is to define an appropriate macroeconomic policy mix to improve macroeconomic performance following common symmetric shocks (Allsopp and Vines, 1998).

In order to define an appropriate policy mix for EMU one first needs to understand the specific problems faced by governments setting fiscal policy in the euro-zone. In this respect, one should note that a crucial feature of EMU is the existence of cross-country demand externalities stemming from the gap between the increasingly global nature of aggregate demand and 
the national bias in production as well as fiscal decisions. In fact, if on the one hand the process of markets integration inevitably fuels the ongoing process of internationalization of demand, the still marginal role played by the euro-zone policy institutions, such as ECOFIN, proves that a national bias in fiscal decision making persists.

To picture this situation in a simple way, one can assume that EMU resembles a multi-sector economy where individuals from different member countries consume both domestic goods and "international" consumption goods. Building on this intuition, this paper proposes a model investigating the impact of public consumption on employment in the presence of imperfect competition on product markets. By redistributing national revenue from the domestic (foreign) to the foreign (domestic) market, fiscal spending is shown to affect firms' profit-margins. In particular, if fiscal spending operates mainly through the international rather than the domestic channel, it may indeed contribute to reduce national firms' market power thus improving the equilibrium level of employment. As economic integration increases, competition becomes fiercer on product markets within the eurozone, in particular because the substitution between national and foreign goods becomes easier. Hence, it is argued that the marginal capability of governments to improve employment through fiscal spending is progressively reduced when product market competition increases: the "optimal" level of spending decreases as a consequence of increased product market competition. Hence, increased economic integration within EMU economies may well lead to a contraction in national public consumption, which would in turn tend to rise equilibrium unemployment. As a consequence, a mechanism of fiscal coordination across EMU member states appears to be necessary to avoid a suboptimal reduction in fiscal spending following increased economic integration.

Finally, this paper submits that due to the existence of cross-country demand externalities within EMU, coordination failures might emerge in the "policy game" between independent fiscal authorities (Gatti and van Wijnbergen, 2002). This coordination failure problem stems from the fact that each national fiscal authority will underestimate the overall impact of increased public consumption on the macroeconomic performance: in a context of "global" demand, any increase in public consumption will be taken by individual fiscal authorities to improve global demand only by a factor proportional to the individual country share in EMU-wide output. This generates a collective action problem leading to sub-optimally low levels of public consumption. This effect is shown to be stronger the larger the number of member countries. 
The paper is organized as follows. Section 2 presents the basic model of imperfect competition and demand externalities. Section 3 introduces the role of fiscal policies in this setup, Section 4 presents an attempt to develop a simple political economy of public consumption in a context of increasing product market integration and Section 5 integrates strategic interactions among national fiscal authorities into the analysis of optimal fiscal spending. Section 6 briefly concludes.

\section{A simple model with demand externalities}

EMU will be characterized here as a multi-sector economy producing one final consumption good taking to represent aggregate cross-country demand. Member countries are represented as "sectors" within he EMU economy: a fixed number $m$ of countries exists, each populated by imperfectly competitive firms producing a single national good. More precisely, I will assume that the representative firm in country $s$ is small with respect to economy but has market power onits own market. The final consumption good is produced competitively according to a constant returns to scale technology using national goods as intermediates. Hence, imperfect competition on the product markets arises because of imperfect substitution across countryspecific intermediates. Imperfections are also present on national labor markets: to generate rigidities in the wage setting process, I will assume that real wages are set according to an efficiency wage mechanism.

\subsection{Market power and demand}

I assume that each national economy is populated by workers and "rentiers". The former category of individual is entitled to wage revenues while the latter earns the profits generated by imperfectly competitive firms. Both workers and rentiers maximize their utility over alternative consumption options, i.e. they select how much of their revenue will be allocated to the consumption of the cross-country good and how much to the consumption of their national good. Utility maximization leads to the result that both rentiers and employed workers use a proportion $\beta$ of their revenue to buy the final cross-country good while a proportion $1-\beta$ of their revenue goes to the purchase of the national good (see Appendix 1 for details). As a consequence, the part of country $s$ national income, which contributes to the international demand for national goods as intermediates, is given by $I_{s}^{i}=\beta \cdot I_{s}$. Note that $I_{s}=\pi_{s}+w_{s} \cdot L_{s}$ is total national income, $\pi_{s}$ being profits, $w_{s}$ the real wage level and $L_{s}$ the level of employment. 
To generate the international demand for national goods, I assume that a "global" consumption good is produced by means of all national intermediates according to a constant returns to scale technology (see Appendix 2 ). Due to the ongoing process of integration of European product markets, it is probably safe to assume that the relative price of country $s$ ' national good is determined on the world market, that is by the international demand for national intermediates, which stems from the production of the crosscountry consumption good. Also, firms will be assumed to be able to take advantage of their market positions on the international demand side and impose the same level of (relative) prices on "sheltered" national markets. Hence, in each country $s$ the representative firm faces a demand for its own good, which is given by:

$$
\frac{P_{s}}{P}=\left(\frac{y_{s}^{i}}{\widetilde{Y} / m}\right)^{-1 / \eta}
$$

$y_{s}^{i}$ being the part of the firm production going as an input to the production of the international consumption good, $\frac{\widetilde{Y}}{m}$ country $s$ ' part in global demand (i.e. production of the final consumption good), $P_{s}$ the price of country $s$ ' national good and $P$ the international final good's price $(\widetilde{Y}$ and $P$ are both defined in Appendix 2). At equilibrium, $y_{s}^{i}$ must equal the part of domestic income that contributes to international demand, that is: $y_{s}^{i}=I_{s}^{i}=\beta \cdot I_{s}$. Moreover, again at equilibrium, aggregate national income equals domestic production: $I_{s}=y_{s}$. One can thus write $y_{s}^{i}=\beta \cdot y_{s}$.

Within country $s$, the representative firm is characterized by a production function which uses labor as its sole input: $y_{s}=\alpha \cdot l_{s}, \alpha$ and $l_{s}$ being respectively labor productivity and the level of employment. Firm profits can be written as $\frac{P_{s}}{P} \cdot \alpha \cdot l_{s}-w_{s} \cdot l_{s}$ with $\frac{P_{s}}{P}=\left(\frac{y_{s}^{i}}{Y / m}\right)^{-\frac{1}{\eta}}, w_{s}$ being the level of the real wage in country $s$ measured in terms of the final good price. Given this setup, profits maximization by the representative firm in country $s$ yields the following first-order condition: $\frac{P_{s}}{P} \cdot \frac{\partial y_{s}}{\partial l_{s}} \cdot\left(1+\frac{\partial P_{s}}{\partial y_{s}} \cdot \frac{y_{s}}{P_{s}}\right)=w_{s}$. From this condition, considering that ex-post the symmetric equilibrium is characterized by $\frac{P_{s}}{P}=1$, one can finally derive ${ }^{1}$ :

$$
\alpha \cdot\left(1-\frac{1}{\eta} \cdot \frac{\beta \cdot y_{s}}{y_{s}^{i}}\right)=w_{s}
$$

The left-hand term of this equation represents labor demand stemming

\footnotetext{
${ }^{1}$ See Appendix 2.
} 
from imperfectly competitive firms: he mark-up term includes a measure of both the intensity of competition (i.e. the elasticity of substitution parameter $\eta$ ) and the firm market share $\frac{\beta \cdot y_{s}}{y_{s}^{i}}$. Because here $y_{s}^{i}=\beta \cdot y_{s}$, the term $\frac{\beta \cdot y_{s}}{y_{s}^{i}}$ simplifies away. However, I will show later on that this asymmetry between the international component of production/demand and total production, leaves some room for public consumption to produce a distortionary effect on national firms' market share and monopolist power. In fact, national fiscal authorities may affect the wedge between national and total production, by means of their fiscal expenditure.

\subsection{Labor market rigidities and equilibrium employment}

Having derived the first-order condition for profit maximization by imperfectly competitive firms, I close the model by defining the wage setting mechanism. I will assume that the real wage is set at the national level according to an efficiency wage mechanism a la Shapiro-Stiglitz [1984]. This allows me to introduce some rigidities in the labor market in a straightforward way ${ }^{2}$. I assume that effort can take two values: 0 in case of shirking and $e$ if no shirking occurs. The probability of detecting a shirker equals $x$. If workers discount the future at a rate $r$, it is shown in Appendix 3 that the real wage fulfilling the no-shirking condition for this economy equals:

$$
w_{s}=\frac{e}{x} \cdot\left(a_{s}+b+x+r\right)
$$

where $a_{s}$ and $b$ are respectively the prevailing hiring and firing rates on the labor market in country $s$. As in most efficiency wage model, I will assume that the firing rate is exogenously given so that firms adjust their labor force by reducing/increasing the hiring rate.

At each moment in time, the equilibrium of flows must hold on the labor market: the amount of new hired workers must equal the amount of fired workers. Therefore, I can define the hiring rate as follows:

$$
a_{s}=b \cdot \frac{L_{s}}{N_{s}-L_{s}}
$$

$L_{s}$ being aggregate employment in country $s$ and $N_{s}$ being country $s$ labor force. From this definition of the hiring rate, I obtain that $a_{s}+b=$ $b \cdot \frac{N_{s}}{N_{s}-L_{s}}$. I can now plug this expression for the hiring and firing rates

\footnotetext{
${ }^{2}$ However, one should note that most results would go through under alternative assumptions concerning the source of rigidities in the wage setting process.
} 
into the first order condition for profit maximization derived in the previous section. By solving for the level of employment, one easily obtains:

$$
L^{*}=N \cdot\left(1-\frac{b \cdot e}{x \cdot \alpha-e \cdot(r+x)-x \cdot \alpha \cdot \frac{1}{\eta}}\right)
$$

where I dropped the subscript $s$ because of symmetry across countries. As one can see, equilibrium employment depends on the intensity of competition -measured by the elasticity of substitution $\eta$ across national goods used as intermediates- as well as on the technological parameter $\alpha$. It can be shown that, as expected:

$$
\begin{aligned}
& \frac{\partial L}{\partial \eta}>0 \\
& \frac{\partial L}{\partial \alpha}>0
\end{aligned}
$$

These results clearly show that increased competition -by reducing profit margins and rents- improves equilibrium employment, as expected. At the same time, a drop in the productivity parameter is shown to push unemployment up. In what follows, a shift in $\alpha$ will be taken to represent the effects of symmetric shocks to the EMU economy.

\section{Role of fiscal policy}

I now turn to investigate the role of public consumption within this simple new-keynesian framework. Fiscal policy has reemerged as an issue in recent economic debate, mostly in relation to a perceived need to ensure some income stabilization in the presence of cross-country shocks, uncertainty and risk-aversion (Andersen, 1999). However, it has also been argued that, in an open economy set-up, equilibrium employment might be affected by demand factors such as fiscal spending (Carlin and Soskice, 2000). The model proposed in this paper adds one important element to the debate as it defines a clear channel by which fiscal spending might affect employment, namely via demand externalities and their impact on firms' market power. To see how this works, I shall now integrate fiscal policies in the simple economy described in previous sections. To do so, I will assume that individual country's government expenditure is financed via non-distortionary wage taxes and that fiscal spending follows a balanced budget rule. For the sake of simplicity, public expenditure will later be specified as a proportion of aggregate production. 


\subsection{Alternative scenarios for public consumption}

I assume that fiscal authorities collect taxes at the national level and then use these resources to contribute to the demand for national goods. This can be done either through "local" spending (i.e. by contributing to the domestic demand for national goods) or through "international" spending, i.e. by contributing to the final demand for the international consumption good. The latter scenario is motivated by the idea that one crucial outcome of European markets integration is the increase in cross-country externalities. As a consequence of these externalities, an increase in public consumption should be expected to benefit national production through the induced increase in aggregate "global" demand rather than through a purely national channel. This scenario seems the most interesting as it pictures one likely evolution in the role of fiscal policies within EMU; moreover, it casts some light on a possible positive role to be played by public consumption in the EMU economy, as it will be shown below. In the following, I will analyze both scenarios in turn ${ }^{3}$.

If one integrates government taxes and spending into the definition of national income, one can easily see that the part of country $s$ ' net national income, which respectively contributes to the international (national) demand for national goods, is given by:

$$
\begin{aligned}
I_{s}^{i} & =\beta \cdot\left(I_{s}-T_{s}\right)+G_{s}^{i} \\
I_{s}^{n} & =(1-\beta) \cdot\left(I_{s}-T_{s}\right)+G_{s}^{n}
\end{aligned}
$$

$G_{s}$ being national public expenditure and $T_{s}$ national taxes financed via wage taxes (see Appendix 5).

Under a first scenario (I), national fiscal authorities collect taxes and then directly spend their tax revenue on national sheltered markets. Hence, $G_{s}^{i}=0$ and $G_{s}^{n}=G_{s}$; one thus obtains:

$$
I_{s}^{i}=\beta \cdot I_{s}-\beta \cdot G_{s} \quad \text { scenario I }
$$

where I make use of the hypothesis of balanced budget i.e. $G_{s}=T_{s}$. Under an alternative scenario (II), fiscal authorities use their tax revenue to contribute to the international demand for national goods as intermediates.

\footnotetext{
${ }^{3}$ Of course, I could also envisage and analyze intermediate scenarios where fiscal spending is distributed via both channels. However, I feel that I can gain more clarity in the analysis if I focus on the two extreme cases; this will help better clarifying my argument, without any significant loss in the generality of results derived hereafter.
} 
In this case, $G_{s}^{n}=0$ and $G_{s}^{i}=G_{s}$; therefore, by imposing the hypothesis of balanced budget $G_{s}=T_{s}$, one has:

$$
I_{s}^{i}=\beta \cdot I_{s}+(1-\beta) \cdot G_{s} \quad \text { scenario II }
$$

The expressions corresponding to the two alternative scenarios for fiscal spending can be summarized as follows:

$$
I_{s}^{i}=\beta \cdot I_{s}+\xi \cdot G_{s}
$$

where $\xi=-\beta$ under the "national spending" scenario (I), and $\xi=1-\beta$ in the "international spending" scenario (II).

One can now consistently defines the international component of the representative firm production as $y_{s}^{i}=\beta \cdot y_{s}+\xi \cdot G_{s}$ where $G_{s}$ is the level of fiscal expenditure fixed by country $s$ 'government. One should note that $G_{s}$ is an endogenous variable in this model. More precisely, it is assumed that fiscal expenditure can be expressed as a proportion of national aggregate income: $G_{s}=g_{s} \cdot I_{s}, g_{s}$ thus representing the control variable for country $s$ government (see Section 4 below). Because the representative firm is small with respect to the economy, $G_{s}$ is taken as given by the firm when maximizing profits. This introduces a wedge between the international demand for national goods as intermediate on the one side and total national production on the other; this wedge is indeed a function of public consumption, which generates some room for fiscal policy to affect the distribution of national income across domestic goods and the international consumption good. As it will be shown below, in this framework public consumption is able to affect firms' market shares and their monopolistic rents. To see this, let me go back to the representative firm's profit maximization.

\subsection{Public consumption and firms market power}

From Equation (2), one knows that $\frac{P_{s}}{P} \cdot \alpha \cdot\left(1-\frac{1}{\eta} \cdot \frac{\beta \cdot y_{s}}{y_{s}^{i}}\right)$ which, by recalling that $y_{s}^{i}=\beta \cdot y_{s}+\xi \cdot G_{s}$ and that $\frac{P_{s}}{P}=1$ in the symmetric equilibrium, can be rewritten as follows (see Appendix 4):

$$
\alpha \cdot\left(1-\frac{1}{\eta} \cdot \frac{\beta}{\beta+\xi \cdot g}\right)=w
$$

where I eliminated the subscript $s$ because of symmetry across countries ${ }^{4}$.

\footnotetext{
${ }^{4}$ The hypothesis of complete symmetry across countries is indeed quite strong. I will partially remove this hypothesis in Section 4 where I will analyze the determination of the "optimal" level of $g$ by national fiscal authorities and come to the problem of fiscal coordination and strategic behavior by individual member countries.
} 
The above condition clearly shows that fiscal authorities can affect firms' profit margins by varying the ratio of public expenditure to total production. This result stems from the fact that the national propensities to consume the international final good equals $\beta<1$; as a consequence, part of national production and demand are kept "sheltered" and directly addressed to national goods: this component of national production/demand does not affect relative prices stemming from international demand for national goods. Hence, public consumption plays a crucial role in this context, as it contributes to redistribute national revenue/demand from domestic (foreign) to foreign (domestic) markets. By this mechanism, fiscal spending can affect the size of national sheltered markets and the market power of firms.

I am now in a position to establish the first result concerning the role of public consumption in this model.

Proposition 1 An increase in public consumption respectively reduces (increases) the mark-up imposed over wages by imperfectly competitive firms if $\xi=1-\beta(\xi=-\beta)$.

The proof of the result is straightforward and simply derives from the first order condition written above. The rationale of the result follows. If $\xi=1-\beta$, an increase in $g$ leads to an increase in the labor demand faced by imperfectly competitive firms. This is a common result in new-keynesian models with demand externalities (Matsuyama [1995] provides a similar result). In my model, this effect stems from the fact that public expenditure can affect firms' production shares via $y^{i}$ and its impact on international demand. In fact, because a part of net national income does not go through international demand, a wedge exists between the international component of demand and total production. Because part of national income is determined by the level $G$ of public expenditure (given to the firm), when maximizing their profits firms consider that an increase in production will only increase demand by a factor $\beta$. This leads firms to misestimate externalities stemming from public consumption, which can then be used to affect their market power.

One should further note that a similar reasoning holds for the case where $\xi=-\beta$. However, under this scenario the prevailing impact of public consumption on demand stems from the negative effects of taxes on the share of disposable income which goes to the international good. Consistently, the effect of increased fiscal spending is in this case to enlarge sheltered markets thus increasing firms market power. 


\subsection{Impact of fiscal spending on equilibrium employment}

I can now proceed as in Section 2.2 and solve the complete model to obtain the equilibrium level of employment. The real wage is still set at the national level, according to an efficiency wage mechanism. Taxes are collected on wages and are assumed to be non-distortionary. This leads to the same specification for the efficiency wage rate as in previous sections ${ }^{5}$. Hence, equilibrium employment can easily be determined by holding $w$ equal to (3) and substituting into (6). Equation (4) now becomes:

$$
L^{*}=N \cdot\left(1-\frac{b \cdot e \cdot(\beta+\xi \cdot g)}{(\beta+\xi \cdot g) \cdot(x \cdot \alpha-e \cdot(r+x))-\beta \cdot x \cdot \alpha \cdot \frac{1}{\eta}}\right)
$$

From this expression for equilibrium employment, one can see that:

$$
\begin{aligned}
& \frac{\partial L}{\partial g}>0 \text { if } \xi=1-\beta \\
& \frac{\partial L}{\partial g}<0 \text { if } \xi=-\beta
\end{aligned}
$$

These results are due to fact that, by boosting public consumption, fiscal authorities generate a distortionary effect, i.e. they reduce (respectively, increase) the profit margins and rises firms' labor demand if $\xi=1-\beta(\xi=$ $-\beta)$. This suggests that in a context of imperfect competition and monopoly rents, national governments can play a crucial role in appropriating those rents and use them "more efficiently", at least with respect to employment.

Given the above results, it appears that national fiscal authorities might have a positive role to play in EMU if they act according to a scenario where public consumption primarily contributes to the international component of consumption and demand. Under this international spending scenario, public consumption also has a stabilizing effect on employment. To see this, recall that equilibrium employment is given by $(7)$ and that $\xi=1-\beta$; then one can show that:

$$
\frac{\partial^{2} L}{\partial \alpha \partial g}<0
$$

\footnotetext{
${ }^{5}$ See Appendix 5. One should further note that alternative assumptions concerning the non-distortionary tax basis could be taken up, for instance a non distortionary profit tax. These modifications would leave my results unchanged..
} 
This means that an increased ratio of public expenditure flattens the response of employment to productivity shocks. The rationale for this result is the following. Increased public consumption operates a redistribution of national income towards the international market where national products are exchanged as intermediate goods. This redistribution yields a reduced market power for firms and a higher perceived elasticity of the demand for goods produced by country $s$ representative firm. As a consequence, the labor demand schedule is flattened and employment reacts less strongly to shocks ${ }^{6}$. Two important results can thus be established.

Proposition 2 Under the "international spending" scenario, an increase in the ratio of public consumption to national production increases equilibrium employment and reduces employment's reaction to productivity shocks

In an imperfectly competitive environment there exists some room for public consumption to produce beneficial distortions that partially offset the adverse employment effects imposed by market power. These beneficial distortions take the form of reduced profit margins (and increased equilibrium employment) and reduced employment volatility as a response to shocks.

\section{Political economy of fiscal spending}

The analysis above pictures a situation where EMU fiscal authorities might indeed have good reasons to adopt a policy of increasing public consumption, as it contrasts monopoly rents and their adverse effects on employment. I will now stick to this particular scenario by assuming that $\xi=1-\beta$ and pursue the line of investigation by asking what would be the optimal level of $g$ that minimizes the loss function characterizing EMU national governments. To do so, I will first consider a situation where governments are "well-coordinated" that is operate as a sort of central fiscal planner: this allows me to derive the optimal level of $g$ corresponding to the symmetric equilibrium for employment derived in the previous sections. I will subsequently turn to the analysis of strategic interactions among fiscal authorities thus allowing for strategic considerations to play a role in the determination of the optimal level of $g$.

\footnotetext{
${ }^{6}$ One can see from (6) that $\frac{d w}{d \alpha}$ becomes larger when public consumption increases.
} 


\subsection{The symmetric equilibrium solution}

For the sake of simplicity, I will assume that national governments aim at keeping employment close to a given target, and that they are ready to adjust public consumption to meet their target. On the other hand, there might be some costs in expanding public consumption; hence, equilibrium employment will not exactly equal the target level. To represent this situation in a simple way, let me define a loss function such as:

$$
U_{G}=\widetilde{L}-L+c \cdot g
$$

This loss function states that national governments have an employment target $\widetilde{L}$ and that some costs $c$ are associated to expanding public consumption. It can easily be shown that $\frac{\partial^{2} L}{\partial^{2} g}<0$. Hence, equilibrium employment is a concave function of public consumption; this ensures that the second order condition associated to the minimization of the loss function is met. Therefore, the loss function above can be used to define an optimal level of $g$ by imposing $\frac{\partial U_{G}}{\partial g}=-\frac{\partial L}{\partial g}+c=0$.

The optimal level of $g$ can be shown to amount to the following:

$$
g^{*}=\frac{\beta}{1-\beta} \cdot\left(\frac{x \cdot \alpha \cdot \frac{1}{\eta}+\sqrt{\frac{1-\beta}{\beta \cdot c} \cdot N \cdot x \cdot \alpha \cdot \frac{1}{\eta} \cdot b \cdot e}}{x \cdot \alpha-e \cdot(r+x)}-1\right)
$$

As expected, the optimal level of public consumption is a function of productivity shocks with the following property:

$$
\frac{\partial g^{*}}{\partial \alpha}<0
$$

that is, a negative (positive) productivity shock generates an increase (decrease) in the level of public consumption.

This result generalizes what I already noted in the previous section regarding the role of public consumption in reducing the impact of shocks. In fact, one sees here that -if governments care about employment- they will rationally decide to run counter cyclical fiscal policies, which translate into employment stabilization. To see that this public consumption rule indeed generates employment stabilization, one can simply compare the reactivity of employment to shocks in the presence and in the absence of reaction from the fiscal authority. In fact, it can be shown that:

$$
\frac{d L}{d \alpha}=\frac{\partial L}{\partial \alpha}+\frac{\partial L}{\partial g^{*}} \cdot \frac{\partial g^{*}}{\partial \alpha}<\frac{\partial L}{\partial \alpha}
$$


where $\frac{d L}{d \alpha}$ represents employment's reaction to shocks with active public consumption while $\frac{\partial L}{\partial \alpha}$ provides the partial reaction without considering active public consumption $\left({ }^{7}\right)$. This proves that public consumption plays a significant stabilizing role (see also figure 2 below).

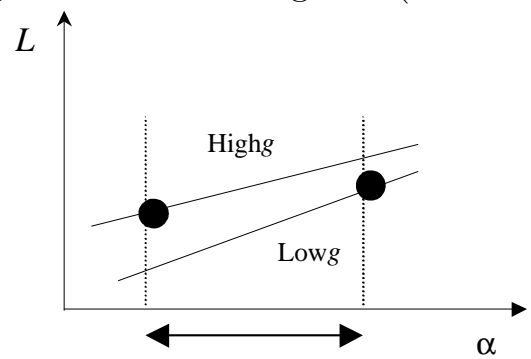

Figure 1. Optimal spending and stabilisation

\subsection{Competition and public consumption}

I now turn to the crucial issue of the interaction between the macroeconomic policy regime and the structure of product markets. As already noted, the question here mostly deals with the impact of market integration on public consumption: is market integration really going to reduce the scope and extent for national governments' intervention? To answer this question, one should note that a major consequence of market integration is the increase in product market competition, i.e. substitution across alternative national intermediates becomes easier. This process is captured in he model by an increase in the elasticity of substitution $\eta$ across intermediates. Hence, a first answer to the question above can be derived by directly studying the impact of increased competition on the optimal level of public consumption. In this respect, it can be shown that $\frac{\partial^{2} L}{\partial g \partial \eta}<0$. This means that the "marginal ability" of governments in improving employment via public consumption decreases when competition becomes fiercer, thus reducing the associated optimal level of $g$. This mechanism explains why the optimal level of $g^{*}$ is such that:

$$
\frac{\partial g^{*}}{\partial \eta}<0
$$

The result clearly illustrates the importance of the interactions between fiscal policy and markets' structure: competition and public spending indeed prove to be two alternative policies to reduce market power and foster

\footnotetext{
${ }^{7}$ Note however that $\frac{d L}{d \alpha}>0$, that is fiscal spending does not over-stabilize employment.
} 
employment. This shows that there exist reasons to believe that competition policies might be a substitute for public consumption in the fight against unemployment.

However, if one turns to investigate the impact of increased competition on employment given the above result, one can easily see that:

$$
\frac{d L}{d \eta}=\frac{\partial L}{\partial \eta}+\frac{\partial L}{\partial g^{*}} \cdot \frac{\partial g^{*}}{\partial \eta}<\frac{\partial L}{\partial \eta}
$$

This shows that the overall positive effect of increased competition on employment proves to be weakened by the side-effect of competition on public consumption. This is stated in the proposition below.

Proposition 3 Increased competition induces a contraction in public spending which has an adverse effect on equilibrium employment

The result stems from the fact that $\frac{\partial g^{*}}{\partial \eta}<0$ and $\frac{\partial L}{\partial g}>0$. On the other hand, it also exists a direct positive effect of competition on employment (recall $\left.\frac{\partial L}{\partial \eta}>0\right)$. Hence, all in all $\frac{d L}{d \eta}>0$ still holds. However, the fact that competition indeed substitutes itself to public consumption leads to a weakening of the overall impact of competition policies on macroeconomic performance i.e. employment. The model thus shows that views relating market integration to a reduced scope for government spending as well as to better employment opportunities are probably correct $^{8}$; however, it should further be noted that the net macroeconomic consequence of the process of integration -notably in terms of improved employment- will prove to be dramatically weakened by the fact that competition actually crowds out beneficial public consumption.

\section{Strategic interactions and fiscal coordination}

The analysis of optimal public consumption has focused up to now on the determination of the optimal level of fiscal spending, i.e. variable $g$, under the implicit assumption that national governments are "well-coordinated". Hence, the analysis as such overlooks some crucial problems linked to the issue of strategic interactions across independent fiscal "players" in a context of global demand externalities. I shall now turn to this issue and try to point

\footnotetext{
${ }^{8}$ However, Amable and Gatti [2001] show that the consequences on employment of an increase in product market competition might be negative if one considers the impact of product market competition on endogenous job turnover. In this case, increased competition induces stronger turnover which might result in lower employment.
} 
out some possible concerns about the good working of EMU policy-making, in relation to fiscal policies in particular.

To do so, I will now assume that $g_{s}$ is a country-specific variable that is set by each fiscal authority by modifying its own level of spending given the other fiscal players' level of spending. Hence, I shall assume that $g_{i}=\bar{g}$ for $\forall i \neq s$. To determine optimal public consumption in this new setup, one has to re-consider the problem faced by each single fiscal authority. Recall that from the first order condition for profit maximization (2) one has:

$\frac{P_{s}}{P} \cdot \alpha \cdot\left(1-\frac{1}{\eta} \cdot \frac{\beta \cdot y_{s}}{y_{s}^{i}}\right)=w_{s}$

where $\frac{\beta \cdot y_{s}}{y_{s}^{i}}=\frac{\beta}{\beta+(1-\beta) \cdot g_{s}}$ is the crucial mark-up term affected by fiscal spending; note that $\frac{P_{s}}{P}$ can not be set equal to 1 here. In fact, we know from (1) that $\frac{P_{s}}{P}=\left(\frac{y_{s}^{i}}{Y / m}\right)^{-1 / \eta}$; hence, because $y_{s}^{i}=\left[\beta+(1-\beta) \cdot g_{s}\right] \cdot y_{s}$, country $s$ ' government will consider, when selecting the level of fiscal expenditure for its own country, that the relative price for domestic goods will also be affected ${ }^{9}$.

To understand how this additional effect might affect equilibrium employment and fiscal decisions, one should note that -the real wage being still set according to equation (3)- employment is now implicitly determined by the following equation:

$$
\begin{aligned}
& \frac{P_{s}}{P} \cdot \alpha \cdot\left(1-\frac{1}{\eta} \cdot \frac{\beta}{\beta+(1-\beta) \cdot g_{s}}\right)=\frac{e}{x} \cdot\left(b \cdot \frac{N_{s}}{N_{s}-L_{s}}+x+r\right) \\
& \text { where } \frac{P_{s}}{P}=\left(\frac{\widetilde{Y}}{m \cdot\left[\beta+(1-\beta) \cdot g_{s}\right] \cdot y_{s}}\right)^{1 / \eta} \text { and } y_{s}=\alpha \cdot L_{s} .
\end{aligned}
$$

In the previous analysis of the symmetric equilibrium, relative price being set to unity, the first left-hand term was absent and increased fiscal spending had a positive impact on labor demand via the induced reduction in firms' profit margins. Now that I consider the non-cooperative solution with independent individual fiscal players, the partial equilibrium effect of public consumption on relative price should be included, which introduces an additional effect of fiscal spending on labor demand. This effect runs via the distortion induced by fiscal spending on relative price: under the international spending scenario public consumption redistributes domestic revenue towards the international market; this tends to reduce the relative

\footnotetext{
${ }^{9}$ Of course, this is only a partial equilibrium reasoning. Ex-post relative price will always equal 1. This relative price effect is similar to the one known in the open-economy literature as "terms-of-trade effect" (see Andersen and Sørensen, 1995). Under the assumption of independent fiscal players, this terms-of-trade effect is shown to yield too expansionary plus domestically biased fiscal policies. My model pictures an alternative situation, where beneficial fiscal spending is indeed downward-biased in the non-cooperative solution.
} 
price for domestic goods, thus lowering firms labor demand. Because of this relative price effect, the beneficial impact of increased fiscal spending for the individual government is weaker than it was in the previous symmetric equilibrium setup. The relative price effect is similar to the terms-of-trade effect pictured in many open-economy models (see footnote 8). However, in my model contrary to the latter an increase in public consumption of domestic goods always generates a negative impact on aggregate employment. As a consequence, there is no domestic spending bias arising here and the international channel is always preferred by fiscal authorities pursuing employment targets.

Indeed, one can show that the marginal benefit (in terms of increased labour demand) from fiscal spending is given by the following expression ${ }^{10}$ :

$$
\left(\frac{\tilde{Y}}{m \cdot\left[\beta+(1-\beta) \cdot g_{s}\right] \cdot y_{s}}\right)^{1 / \eta} \cdot \alpha \cdot(1-\beta) \cdot[\beta-(1-\beta) \cdot g \cdot \eta]
$$

(8) captures the increase in labour productivity (i.e. demand) induced by increased fiscal spending by one single member country. The term is positive provided that $\frac{\beta}{1-\beta}>g \cdot \eta$, i.e. if competition -measured by the elasticity of substitution $\eta$ - is not too strong. The rational for this result is the following. When competition increases on product markets, the direct positive effect of $g_{s}$ on firms' labor demand (via reduced mark-up) is reduced (see Section 4.2). As a consequence, the negative impact stemming from relative price distortion becomes predominant when product market competition is stronger. This pictures a situation where increased competition on the product market might lead national fiscal authorities to sub-optimally reduce fiscal spending in response to economic integration.

Results concerning the level of public consumption $\widehat{g}^{*}$ selected by independently interacting fiscal authorities are stated in the proposition below.

Proposition 4 If $\frac{\beta}{1-\beta}>g \cdot \eta$ the level of public consumption $\widehat{g}^{*}$ is positive but lower than the optimal level $g^{*}$.

\section{$\mathbf{P}$ roof. Appendix 6}

\footnotetext{
${ }^{10}$ This marginal benefit is calculated by assuming that each national government takes aggregate EMU production $\widetilde{Y}$ as given. However, similar results could be derived under the weaker assumption that each individual government integrates the impact on $\widetilde{Y}$ of the increase in its own public consumption -given the level of public consumption of other governments
} 
This result stems from the fact that national governments -by acting as individual independent players- will not consider the response of other "players" to their own increase in public consumption. As a consequence, each national fiscal authority will underestimate the overall effect of fiscal expenditure on employment. Hence, the marginal benefit of increasing public consumption for an individual fiscal authority is lower than the aggregate marginal benefit, which points to one important source of coordination failure in a multi-sector economy such as EMU.

Finally, one can see that (8) is decreasing in the number $m$ of countries which are effective members of EMU, which leads to the conclusion that $\frac{\partial \widehat{g}^{*}}{\partial m}<0$. These results underline a possible "race-to-the-bottom" effect in public consumption that would stem from the progressive "dilution" of individual country impact on global demand and the subsequent reduced awareness of fiscal decision-makers about the benefits from their fiscal spending. Hence, a mechanisms of fiscal coordination appears necessary in this context, to avoid a suboptimal contraction in national public consumption following the enlargement of the EMU economy.

\section{Conclusion}

This paper suggests that the changing structure of product markets has a crucial impact on the role of public spending in a multi-sector economy such as EMU. In the presence of imperfections on the product market, which prevent the absorption of rents generated by firms' market power, public spending constitutes a possible way to re-appropriate those rents and redistribute them towards international markets. This allows to compress profit margins and to achieve a better macroeconomic performance - at least from the point of vue of equilibrium employment. Hence, the paper argues that fiscal policy operating through the international channel can in principle play a constructive role within EMU macroeconomic policy regime; at the same time, it is also shown that fiscal spending operating via the domestic channel reinforces sheltered markets thus inducing lower labor demand and employment levels. However, the model shows that market integration, by increasing the intensity of product market competition, might induce a contraction of rent-reducing public consumption thus generating a negative side-effect on employment. This constitutes a first concern with respect to the likely working of EMU policy mix, which calls for the design of a suitable fiscal coordination mechanism.

A second concern for EMU is related to the existence of important de- 
mand externalities within EMU, externalities which are not necessarily integrated by independently interacting fiscal players. In such a context, individual governments are inclined to consider that -by modifying national public consumption- they affect the relative price for domestic goods. This "relative price" effect leads individual governments to underestimate the positive impact on employment of expanding public consumption via the international channel. Hence, again fiscal coordination is needed to ensure that EMU economies will indeed fully benefit from their fiscal spending.

\section{Appendix}

\section{.1 Consumption}

Instantaneous utilities for individual consumers are defined as follows. For employed workers:

$$
u t_{w}=u_{w}-e
$$

The term $u_{w}$ is the utility associated with consumption and $e$ is the disutility of effort.

As there is no unemployment benefits, the instantaneous utility of unemployed workers is zero. "Rentiers" only earn profits and their utility is equal to:

$$
u t_{r}=u_{r}
$$

I further assume that $u_{j}=\left(\frac{h_{c j}}{\beta}\right)^{\beta} \cdot\left(\frac{h_{d j}}{1-\beta}\right)^{1-\beta}$ with $j=w, r ; h_{c}$ represents the consumption of the cross-country good and $h_{d}$ the consumption of the domestic good. Utility is maximized under the individual budget constraints: $h_{c w}+h_{d w}=w$ for workers and $h_{c r}+h_{d r}=\pi$ for rentiers, $w$ being the real wage rate and $\pi$ real profits. Maximization leads to the following conditions:

$h_{c}=h_{c w}+h_{c r}=\beta \cdot(w+\pi)$

$h_{d}=h_{d w}+h_{d r}=(1-\beta) \cdot(w+\pi)$

where $\beta$ represents the individual propensity to consume the final crosscountry good. Ex-post utility for individuals of either types is given by:

$$
\begin{aligned}
& u_{w}=w \\
& u_{r}=\pi
\end{aligned}
$$

This specification will prove to be very useful in the following, namely when I will proceed to solve the efficiency wage part of the model: in fact, I will then simply hold instantaneous utility equal to $u t_{w}=w-e$ (see Appendix 3 below). One should further note that in principle employed workers' utility (determined by consumption decisions) depends on net wage 
and therefore on taxes - that I will introduce later on. However, it is indeed possible to specify the tax rate in such a way that it is non distortionary with respect to the efficiency wage rate. I will adopt this specification as I am not interested in allowing for tax distortions in this paper.

\section{.2 International demand}

Utility maximization leads to the result that both rentiers and employed workers use a proportion $\beta$ of their revenue for the consumption of the final good while a proportion $1-\beta$ of their revenue goes to the purchase of the national good. To derive the demand function faced by imperfectly competitive firms on their national product market, I assume that there is one final consumption good that is produced using all national goods as intermediates, according to a constant returns to scale technology:

$$
\tilde{Y}=m^{1 /(1-\eta)} \cdot\left(\sum_{s=1}^{m}\left(y_{s}^{i}\right)^{\frac{\eta-1}{\eta}}\right)^{\frac{\eta}{\eta-1}} \text { with } \eta>1
$$

$y_{s}^{i}$ being the part of the production of the representative firm in country $s$ effectively going to the production of the international consumption good. Profit maximization on the competitive final good market yields:

$$
y_{s}^{i}=\left(\frac{P_{s}}{P}\right)^{-\eta} \cdot \frac{\widetilde{Y}}{m}
$$

with the price index defined as follows:

$$
P=\left(\frac{1}{m} \cdot \sum_{s=1}^{m} P_{s}^{1-\eta}\right)^{\frac{1}{1-\eta}}
$$

Hence, the inverse demand function can be derived:

$$
\frac{P_{s}}{P}=\left(\frac{y_{s}^{i}}{\widetilde{Y} / m}\right)^{-\frac{1}{\eta}}
$$

Firms maximize their profits on their national product market, given the above inverse demand function. Profit maximization leads to the following first order condition:

$$
\begin{aligned}
& \frac{P_{s}}{P} \cdot \frac{\partial y_{s}}{\partial l_{s}} \cdot\left(1+\frac{\partial P_{s}}{\partial y_{s}} \cdot \frac{y_{s}}{P_{s}}\right)=w_{s} \\
& \text { Given that: } \\
& \frac{\partial P_{s}}{\partial y_{s}}=-\frac{1}{\eta} \cdot\left(\frac{y_{s}^{i}}{\widetilde{Y} / m}\right)^{-\frac{1}{\eta}-1} \cdot \frac{\beta}{\widetilde{Y} / m} \cdot P
\end{aligned}
$$

the left-hand side can finally be rewritten:

$$
\frac{P_{s}}{P} \cdot \alpha \cdot\left(1-\frac{\beta}{\eta} \cdot \frac{y_{s}}{y_{s}^{i}}\right)
$$

In the symmetric equilibrium, one can safely assume that $\frac{P_{s}}{P}=1$; hence, one finally gets to the following first-order condition:

$$
\alpha \cdot\left(1-\frac{1}{\eta} \cdot \frac{\beta \cdot y_{s}}{y_{s}^{i}}\right)=w_{s}
$$




\section{$.3 \quad$ Efficiency wage solution}

I assume that effort can take two values: 0 in case of shirking and $e$ if no shirking occurs. The probability of detecting a shirker equals $x$. The flows probability in and out unemployment are respectively given by $b$ and $a$, the latter being the value of the endogenous hiring rate. The efficiency wage is fixed by the no-shirking condition given the following definition of intertemporal utilities associated with the alternative strategies of shirking and non-shirking:

1. $r \cdot U=a \cdot\left(V_{N S}-U\right)$

2. $r \cdot V_{S}=w+(x+b) \cdot\left(U-V_{S}\right)$

3. $r \cdot V_{N S}=w-e+b \cdot\left(U-V_{N S}\right)$

One can easily see that the no-shirking condition $V_{S}=V_{N S}$ implies:

4. $V-U=\frac{e}{x}$

From (1) one also has:

$U=\frac{a}{a+r} \cdot V$

I can now substitute this result into (4) thus obtaining:

$V=\frac{e}{x} \cdot \frac{a+r}{r}$

If one substitutes this expression into (2), one finally has:

$\frac{e}{x} \cdot(a+r)=w-(x+b) \cdot \frac{e}{x}$

which yields:

$w=\frac{e}{x} \cdot(a+b+r+x)$

\section{.4 Fiscal spending}

Fiscal authorities collect taxes at the national level and then use public consumption to contribute to the demand for national goods. Hence, as shown in the paper, the part of net national income that contributes to international demand for intermediate national goods is given by:

$$
I_{s}^{i}=\beta \cdot\left(I_{s}-T_{s}\right)+G_{s}=\beta \cdot I_{s}+\xi \cdot G_{s}
$$

where I make use of the hypothesis of balanced budget i.e. $G_{s}=T_{s} ; G_{s}$ is national public expenditure and $T_{s}$ represents national taxes financed via wage taxes; $I_{s}$ equals total revenue in country $s$ that is $\pi_{s}+w_{s} \cdot L_{s}$. It should be noted that the part of the national income that is directly addressed to the purchase of the domestic good constitutes the "sheltered" part of the demand for the national good. Let me now focus on the international scenario for fiscal spending. In this case, one can write $I_{s}^{i}=\beta \cdot\left(I_{s}-T_{s}\right)+$ 
$G_{s}=\beta \cdot I_{s}+(1-\beta) \cdot G_{s}$. Consistently, one can express the international component of the representative firm production in country $s$ as follows:

$y_{s}^{i}=\beta \cdot y_{s}+(1-\beta) \cdot G_{s}$

where $G_{s}$ is the (endogenous) level of fiscal expenditure fixed by country $s$ government as a proportion of national aggregate income, $G_{s}=g_{s} \cdot I_{s}$ (and therefore taken as given by the firm).

Profit maximization by the representative firm yields a similar condition as before, that is $\alpha \cdot\left(1-\frac{1}{\eta} \cdot \frac{\beta \cdot y_{s}}{y_{s}^{i}}\right)=w_{s}$. However, we know that $y_{s}^{i}=$ $\beta \cdot y_{s}+(1-\beta) \cdot G_{s}$ and, by considering that at the equilibrium $G_{s}=g_{s} \cdot y_{s}$ one obtains:

$\alpha \cdot\left(1-\frac{1}{\eta} \cdot \frac{\beta \cdot y_{s}}{\left[\beta+(1-\beta) \cdot g_{s}\right] \cdot y_{s}}\right)=w_{s}$

Simplifying for $y_{s}$ one finally has:

$\alpha \cdot\left(1-\frac{1}{\eta} \cdot \frac{\beta}{\beta+(1-\beta) \cdot g}\right)=w$

where I dropped the suffix $s$ because of symmetry across countries.

One can see that fiscal authorities can affect firms' profit margins by varying the ratio of public expenditure to total production. In particular, an increase in $g$ leads to an increase in the labor demand faced by imperfectly competitive firms.

\section{$.5 \quad$ Wage setting and taxes}

Because I want to consider in this paper only non-distortionary taxes, I assume that taxes are specified as a proportion of the wage surplus:

$T=t \cdot(w-e)$

where $w=$ real wage and $e=$ effort. Hence the net wage surplus is given by:

$w-e-t \cdot(w-e)=(1-t) \cdot(w-e)$

We already know that effort can take two values: 0 in case of shirking and $e$ if no shirking occurs. Therefore, the net wage surplus becomes $(1-t) \cdot w$ when $e=0$. The intertemporal utilities associated with the alternative strategies of shirking and non-shirking can now be written:

1. $r \cdot U=a \cdot\left(V_{N S}-U\right)$

2. $r \cdot V_{S}=(1-t) \cdot w+(x+b) \cdot\left(U-V_{S}\right)$

3. $r \cdot V_{N S}=(1-t) \cdot(w-e)+b \cdot\left(U-V_{N S}\right)$

Hence, the no-shirking condition $V_{S}=V_{N S}$ now implies $V-U=$ $\frac{e}{x} \cdot(1-t)$. Substituting $U=\frac{a}{a+r} \cdot V$ into the previous equation, one obtains: 
$V=\frac{e}{x} \cdot(1-t) \cdot \frac{a+r}{r}$

Finally, by substituting this result into (2), one finally has: $\frac{e}{x} \cdot(1-t) \cdot(a+r)=w \cdot(1-t)-(x+b) \cdot \frac{e}{x} \cdot(1-t)$

where $(1-t)$ simplifies away, which yields the same level of real wage as previously derived.

\section{.6 Coordination}

The first-order condition for profit maximization yields:

$\frac{P_{s}}{P} \cdot \alpha \cdot\left(1-\frac{1}{\eta} \cdot \frac{\beta}{\beta+(1-\beta) \cdot g_{s}}\right)=\frac{e}{x} \cdot\left(b \cdot \frac{N_{s}}{N_{s}-L_{s}}+x+r\right)$

where $\frac{P_{s}}{P}=\left(\frac{\widetilde{Y}}{m \cdot\left[\beta+(1-\beta) \cdot g_{s}\right] \cdot y_{s}}\right)^{1 / \eta}$ and $y_{s}=\alpha \cdot L_{s}$.

Let me define the two functions $\Psi\left(g_{s}, L_{s}\right)=\left(\frac{\widetilde{Y}}{m \cdot\left[\beta+(1-\beta) \cdot g_{s}\right] \cdot y_{s}}\right)^{1 / \eta} \cdot \alpha$. $\left(1-\frac{1}{\eta} \cdot \frac{\beta}{\beta+(1-\beta) \cdot g_{s}}\right)$ and $w\left(L_{s}\right)=\frac{e}{x} \cdot\left(b \cdot \frac{N_{s}}{N_{s}-L_{s}}+x+r\right)$. I assume that aggregate EMU demand $\tilde{Y}$ is taken as given by individual government selecting their optimal fiscal spending (see footnote 9). To derive the optimal level of fiscal spending all what one needs to know is the derivative of equilibrium employment with respect to variable $g$. This derivative is given by:

$\frac{d L_{s}}{d g_{s}}=\frac{\Psi_{g_{s}}^{\prime}}{w_{L_{s}}^{\prime}-\Psi_{L_{s}}^{\prime}}$

where $\Psi_{g_{s}}^{\prime}>0$ and $\Psi_{L_{s}}^{\prime}<0$. The corresponding derivative for the symmetric equilibrium solution is given by:

$\frac{d L}{d g}=\frac{\Psi_{g}^{\prime}}{w_{L}^{\prime}}$.

As $\Psi_{g_{s}}^{\prime}<\Psi_{g}^{\prime}$, the above analysis clearly yields $\frac{d L_{s}}{d g_{s}}<\frac{d L}{d g}$ which in turn implies $\widehat{g}^{*}<g^{*}$.

\section{References}

[1] Allsopp, C. and D. Vines [1998] 'The Assessment: Macroeconomic Policy after EMU', Oxford Review of Economic Policy, 14:1-23.

[2] Amable, B. and D. Gatti [2002] Macroeconomic effects of product market competition in a dynamic efficiency wage model, Economics Letters, 75:1, 39-46.

[3] Andersen, T.M. [1999] International Integration, Risk and the Welfare State, EPRU Working Paper 2000-2, forthcoming Scandinavian Journal of Economics. 
[4] Andersen, T.M. and Sørensen, J.R. [1995] Unemployment and Fiscal Policy in the Economic and Monetary Union, European Journal of Political Economy, 11:27-43.

[5] Artis, M. J. and Winkler, B. [1997] The Stability Pact: Safeguarding the Credibility of the European Central Bank, CEPR Discussion Paper 1688 .

[6] Beetsma, R. and Uhlig, H. [1999] An Analysis of the Stability and Growth Pact, The Economic Journal, 109:546-71.

[7] Buti, M., Franco, D. and Ongena, H. [1998] Fiscal Discipline and Flexibility in EMU: the Implementation of the Stability and Growth Pact', Oxford Review of Economic Policy 14: 81-97.

[8] Canzoneri, M. and Diba, B.T. (1999). 'The Stability and Growth Pact: A Delicate Balance or an Albatross?', Paper prepared for the Austrian National Bank's Workshop on 'Challenges for Economic Policy Coordination within EMU', January 22 (Second Draft February).

[9] Carlin, W. and D. Soskice [2000] Unique or Multiple NAIRUs: Modern versus Heckscher-Ohlin Theories of Trade, mimeo, WZB.

[10] Gatti, D. and C. van Wijnbergen [2002] Co-ordinating Fiscal Authorities in the Euro-zone. A Key Role for the ECB, Oxford Economic Papers, 54:56-71.

[11] Matsuyama, K. [1995] Complementarities and Cumulative Processes in Models of Monopolistic Competition, Journal of Economic Literature, XXXIII:701-729.

[12] Shapiro C. and Stiglitz J. [1984] Equilibrium unemployment as a worker discipline device, American Economic Review, 74: 433-444.

[13] Soskice, D. and T. Iversen [1998] Multiple Wage-Bargaining Systems in the Single Currency Area, Oxford Review of Economic Policy, 14: 110-24. 


\section{IZA Discussion Papers}

\begin{tabular}{|c|c|}
\hline No. & Author(s) \\
\hline 480 & G. Saint-Paul \\
\hline 481 & E. Schlicht \\
\hline 482 & $\begin{array}{l}\text { P. Kuhn } \\
\text { C. Weinberger }\end{array}$ \\
\hline 483 & $\begin{array}{l}\text { H. Rapoport } \\
\text { A. Weiss }\end{array}$ \\
\hline 484 & $\begin{array}{l}\text { J. H. Bishop } \\
\text { L. Woessmann }\end{array}$ \\
\hline 485 & $\begin{array}{l}\text { L. Woessmann } \\
\text { M. R. West }\end{array}$ \\
\hline 486 & $\begin{array}{l}\text { A. L. Booth } \\
\text { M. L. Bryan }\end{array}$ \\
\hline 487 & $\begin{array}{l}\text { R. L. Lumsdaine } \\
\text { E. S. Prasad }\end{array}$ \\
\hline 488 & $\begin{array}{l}\text { A. Ciccone } \\
\text { G. Peri }\end{array}$ \\
\hline 489 & $\begin{array}{l}\text { D. Del Boca } \\
\text { S. Pasqua }\end{array}$ \\
\hline 490 & W. F. Richter \\
\hline 491 & $\begin{array}{l}\text { R. Rotte } \\
\text { C. M. Schmidt }\end{array}$ \\
\hline 492 & $\begin{array}{l}\text { R. Lalive } \\
\text { J. Zweimüller }\end{array}$ \\
\hline 493 & $\begin{array}{l}\text { R. M. Leontaridi } \\
\text { M. E. Ward }\end{array}$ \\
\hline 494 & $\begin{array}{l}\text { J. Wagner } \\
\text { R. Sternberg }\end{array}$ \\
\hline 495 & $\begin{array}{l}\text { J. T. Addison } \\
\text { L. Bellmann } \\
\text { C. Schnabel } \\
\text { J. Wagner }\end{array}$ \\
\hline 496 & $\begin{array}{l}\text { M. P. Keane } \\
\text { E. S. Prasad }\end{array}$ \\
\hline 497 & D. Gatti \\
\hline
\end{tabular}

Title

Area

Date

The Complexity of Economic Policy:

$04 / 02$

I. Restricted Local Optima in Tax Policy Design

6

Hiring Standards and Market Clearing

04/02

Leadership Skills and Wages

04/02

In-Group Cooperation in a Hostile Environment:

$04 / 02$

An Economic Perspective on Some Aspects of Jewish Life in (Pre-Modern) Diaspora

Institutional Effects in a Simple Model of

$04 / 02$

Educational Production

Class-Size Effects in School Systems Around

04/02

the World: Evidence from Between-Grade

Variation in TIMSS

Who pays for General Training? New Evidence

for British Men and Women

Identifying the Common Component of

$04 / 02$

International Economic Fluctuations:

A New Approach

Identifying Human Capital Externalities:

04/02

Theory with an Application to US Cities

Employment Patterns of Husbands and Wives

and Family Income Distribution in Italy (1977-

1998)

Social Security and Taxation of Labour Subject 2

05/02

to Subsidiarity and Freedom of Movement

On the Production of Victory: Empirical Deter-

minants of Battlefield Success in Modern War

5

05/02

Benefit Entitlement and Unemployment

05/02

Duration: The Role of Policy Endogeneity

Work-Related Stress, Quitting Intentions and 5

05/02

Absenteeism

The Role of the Regional Milieu for the Decision 1

05/02

to Start a New Firm: Empirical Evidence for

Germany

German Works Councils Old and New:

05/02

Incidence, Coverage and Determinants

Changes in the Structure of Earnings During the 4

Polish Transition

European Integration and Employment: 